\title{
Renata Brajer-Marczak
}

Uniwersytet Ekonomiczny we Wrocławiu

e-mail: renata.brajer-marczak@ue.wroc.pl

\section{BARIERY UPOWSZECHNIANIA MODELI DOJRZAŁOŚCI PROCESOWEJ}

\section{BARRIERS TO THE DISSEMINATION OF PROCESS MATURITY MODELS}

DOI: $10.15611 / \mathrm{pn} .2017 .463 .11$

Streszczenie: $\mathrm{W}$ artykule podjęto próbę identyfikacji i klasyfikacji barier upowszechniania się modeli dojrzałości procesowej. W pierwszej kolejności przybliżono istotę dojrzałości procesowej i modeli dojrzałości procesowej. Odniesiono się do różnorodności powyższych modeli opisywanych w literaturze. Zaprezentowano korzyści płynące z ich implementacji. Następnie, bazując na przeprowadzonych studiach aktualnej krajowej i zagranicznej literatury przedmiotu, analizie poddano zidentyfikowane ograniczenia ich stosowania. W końcowej części opracowania dokonano podziału barier stosowania modeli dojrzałości procesowej, dzieląc je na wewnętrzne i zewnętrzne. Szerszą uwagę skupiono na ograniczeniach o charakterze wewnętrznym, w nich upatrując głównych przyczyn braku zainteresowania, jak i wdrażania modeli dojrzałości procesowej. Podzielono je na: zarządcze finansowe, personalne, kulturowe, organizacyjne i techniczne. Wśród barier zewnętrznych uwagę zwrócono na cechy otoczenia rynkowego, branżę, w której funkcjonuje podmiot, trendy i mody na stosowanie określonych narzędzi wspomagających zarządzanie, oraz wymagania dostawców i odbiorców.

Słowa kluczowe: zarządzanie procesami, dojrzałość procesowa, modele dojrzałości procesowej, bariery, użyteczność modeli.

Summary: The paper aims to identify and classify barriers to the dissemination of process maturity models. First, the essence of process maturity and process maturity models were approached. The reference to the diversity of the models described in the literature was made along with the presentation of the benefits of their implementation. Next, based on the current domestic and foreign literature review, indicated restrictions in their implementation were analysed. In the final part, the division of the barriers to the use of process maturity models was made breaking them down to internal and external barriers. Closer attention was paid to the difficulties of the internal nature, to which the main reasons for the lack of interest in as well as implementation of process maturity models were ascribed. They were divided into: managerial, financial, personal, cultural, organisational and technical barriers. Among the external barriers, attention was given to the characteristics of the market environment, type of business in which the subject operates, trends in the application of certain tools supporting the management and requirements of suppliers and customers.

Keywords: process management, process maturity, process maturity models, barriers, usefulness of models. 


\section{Wstęp}

Nauki o zarządzaniu wykorzystują termin „dojrzałość” w różnych aspektach. Dojrzałość organizacji to stan odzwierciedlający pewien poziom umiejętności, a także doskonałości. O dojrzałości świadczy stopień przygotowania organizacji do pełnienia zadań, realizacji celów w kompleksowy sposób [Skrzypek 2012, s. 402]. Określenie dojrzałość pojawiło się w naukach o zarządzaniu wraz z pojęciem cyklu życia organizacji. Zgodnie $\mathrm{z}$ nim organizacja $\mathrm{w}$ trakcie swojego istnienia przechodzi kilka etapów, które różnią się zarówno pod względem ilościowym, jak i jakościowym. Wskazywano na narodziny, wzrost, dojrzałość i schyłek. W tym rozumieniu poszczególne etapy, w tym również dojrzałość, utożsamiano z wiekiem organizacji, a sama dojrzałość organizacji oznaczała „stan [...] ostatecznie uformowany, osiągnięcie ostatecznego etapu rozwoju lub procesu kształtowania" [sjp.pl].

Z perspektywy dojrzałości procesowej mówimy o zakresie, w jakim organizacje wyraźnie i konsekwentnie dokumentują, mierzą, kontrolują i stale doskonalą procesy [CMMI-DEV 2010]. Samo osiąganie dojrzałości procesowej jest ciągłym procesem o długookresowej perspektywie, który wymaga osiągania kolejnych stadiów, określanych mianem poziomów dojrzałości. W tym ujęciu dojrzałość ma charakter stopniowalny, może być mniejsza lub większa. Poszczególne poziomy dojrzałości procesowe tworzą strukturę modeli dojrzałości procesowej. Są one obecnie bardzo popularnymi sposobami oceny dojrzałości procesowej, opisywanymi w literaturze przedmiotu. Opracowywane są one zarówno przez akademików, organizacje, najczęściej duże korporacje, jak i firmy doradcze, które sugerują wiele korzyści z ich wprowadzania. W aktualnej literaturze dużo miejsca zajmuje opis podobieństw i różnic między poszczególnymi modelami, analizowana jest też ich struktura. $\mathrm{Z}$ drugiej strony zarówno w literaturze przedmiotu, jak i w praktyce brakuje pogłębionej dyskusji o efektach stosowania modeli dojrzałości procesowej, w powiązaniu z wynikami całej organizacji, i jak wskazuje M. Rohloff, poza modelami BPMM opracowanym przez Object Management Group i CMMI opracowanym przez Software Engineering Institute nie znajdują częstego zastosowania w praktyce gospodarczej [Rohloff 2009]. Rodzi się zatem pytanie o bariery i ograniczenia upowszechniania się modeli dojrzałości procesowej. Celem niniejszego opracowania jest próba identyfikacji i klasyfikacji barier upowszechniania się modeli dojrzałości procesowej. Cel ten jest o tyle istotny, że wiele publikacji skupia się na opisie konstrukcji poszczególnych modeli, wskazaniu ich istoty oraz zalet [vom Brocke, Rosemann 2015], porównaniu między sobą [Röglinger, Pöppelbuß, Becker 2012], a zagadnienie możliwości ich praktycznego zastosowania podejmowane jest w literaturze stosunkowo rzadko [Pöppelbuß, Röglinger 2011]. Dla realizacji wskazanego celu przeprowadzono studia aktualnej krajowej i zagranicznej, głównie anglojęzycznej, literatury przedmiotu. 


\section{Istota modeli dojrzałości procesowej}

Dojrzałość procesowa to stan organizacji oznaczający osiągnięcie przez nią pełnego poziomu rozwoju procesowego. Najczęściej definiowana jest jako zdolność organizacji do takiego realizowania procesów, które systematycznie dostarcza coraz lepszych rezultatów procesów i w efekcie poprawia wyniki całej organizacji [Rosemann, de Bruin 2005]. Można ją też rozumieć jako zdolność organizacji do efektywnego zarządzania procesami wspierającymi realizację celów strategicznych. Wskazuje się tu na dwojaką zależność, po pierwsze - cele procesów wynikać muszą z celów strategicznych, a po drugie - osiąganie zaplanowanych celów procesów umożliwia realizację strategii [Brajer-Marczak 2012, s. 516]. Ujmując dojrzałość procesową organizacji kompleksowo, można ją sformułować jako stopień umiejętności strategicznego doboru i powiązania procesów (architektura procesów) oraz operacyjnego zarządzania nimi w aspekcie: funkcjonalnym, instrumentalnym i instytucjonalnym, służących realizacji celów organizacji i zapewniających jej rozwój poprzez ciągłe doskonalenie [Nowosielski 2012, s. 357].

J. Auksztol i M. Chomuszko wskazują, że dojrzałość procesowa to pojęcie, którego inspiracje wywodzą się zarówno z zarządzania jakością, jak i problematyki tzw. dobrych praktyk biznesowych [Auksztol, Chomuszko 2012, s. 42], a sam zamysł oceny dojrzałości procesowej wywodzi się z koncepcji TQM oraz zarządzania procesowego. Niewątpliwie zwiększanie stopnia dojrzałości procesowej koresponduje także z koncepcją Organizacyjnego Rozwoju (OD), za której prekursora uznaje się Kurta Lewina [Leksykon zarzadzania 2004].

Aby określić poziom dojrzałości procesowej w organizacji, ocenie poddaje się stosowane metody i techniki zarządzania procesami w skali całej organizacji [Bitkowska 2009, s. 155]. A. Kucińska-Landwójtowicz oraz M. Kołosowski definiują poziom dojrzałości procesowej jako stopień wdrożenia wytycznych zawartych w modelach dojrzałości procesowej [Kucińska-Landwójtowicz, Kołosowski 2012]. Taką ocenę umożliwiają modele dojrzałości procesowej (Business Process Maturity Models BPMM) wspierające zarządzanie procesami biznesowymi (BPM). Ogólnie można je scharakteryzować jako zestawy zaleceń i dobrych praktyk w zakresie uzyskiwania sprawności realizowanych procesów. Opisują one ewolucyjną ścieżkę rozwoju umożliwiającą organizacji przejście od stanu niespójnych, niepowiązanych ze sobą procesów do procesów uporządkowanych, monitorowanych, zarządzanych i doskonalonych. Za prekursora koncepcji dochodzenia do dojrzałości organizacyjnej uznaje się R. Nolana, który na początku lat 70. minionego wieku opracował Teorię Etapów Rozwoju [Nolan, Gibson 1974]. Wyróżnił on fazy rozwoju technologii informatycznych, wspierające pozostałe funkcje organizacji. Idea modeli dojrzałości opiera się na założeniu, że istnieją przewidywalne wzorce ewolucji i zmian, odzwierciedlane w kolejnych poziomach, które w sumie pokazują pożądaną lub logiczną ścieżkę rozwoju od stanu początkowego do pełnej dojrzałości [Pöppelbuß, Röglinger 2011]. 
Pierwszy model dojrzałości Quality Management Maturity Grid opracowany został pod koniec lat 70. przez Ph. Crosby’ego. Dotyczył on zarządzania jakością, wyróżniono w nim pięć okresów dojrzałości. Okresy te zostały scharakteryzowane w sześciu kategoriach, tj. poziom zrozumienia i stosunek do problemu wyrażany przez kierownictwo, status organizacji jakości, podejście do problemów, udział kosztów jakości w stosunku do wpływów ze sprzedaży, działania na rzecz usprawniania jakości, ocena postawy przedsiębiorstwa [Skrzypek 2012, s. 401]. Za pomocą opracowanego kwestionariusza przedsiębiorstwa mogły w skali od 1 do 5 ocenić stopień zaawansowania w stosowaniu określonych narzędzi zarządzania jakością. Model pokazywał, jakie działania należy wdrożyć, aby osiągnąć kolejny stopień dojrzałości. Zapoczątkowało to trwającą do dzisiaj tendencję opracowywania modeli dojrzałości w różnych obszarach organizacji, w tym również dla potrzeb zarządzania procesowego.

W 1989 roku Watts S. Humphrey po raz pierwszy przedstawił zasady oceny dojrzałości procesowej. Stanowiło to punkt wyjścia do opracowania pierwszego modelu oceny dojrzałości procesów Capability Maturity Model (CMM) przez Software Engineering Institute Carnegie Mellon University [Kalinowski 2011, s. 174]. Z przeglądu dostępnej literatury przedmiotu wynika, że nie ma jednej obowiązującej definicji modelu dojrzałości procesowej. Większość definicji opisuje poziomy zdolności, zachowań i cele modelu [Albliwi i in. 2014]. W niniejszym opracowaniu przyjęto, że jest to „uporządkowany zbiór elementów, który opisuje cechy efektywnych procesów na różnych etapach rozwoju. Wskazuje również punkty rozgraniczające poszczególne etapy i wskazuje metody przechodzenia z jednego poziomu do drugiego" [Pullen 2007, s. 11].

Obecnie w większości przypadków modele dojrzałości procesowej jako punkt wyjścia traktują określenie stanu istniejącego realizowanych procesów (tzw. as-is state), natomiast celem ich stosowania jest osiągnięcie określonego stanu dojrzałości procesowej (tzw. to-be state) [Kalinowski 2011, s. 16]. Tworzenie modeli dojrzałości procesowej jest $\mathrm{z}$ jednej strony próbą holistycznego podejścia do zagadnienia doskonałości organizacji, z drugiej zaś jest tworzeniem skutecznego narzędzia dla menedżerów ukierunkowanych na doskonalenie zarządzania [Haffer 2011, s. 37]. Modele dojrzałości procesowej uznać można również za narzędzie pomiaru i oceny wyników organizacyjnych. Posługiwanie się nimi ma wiele zalet, przede wszystkim umożliwia zdiagnozowanie stanu, w którym obecnie znajduje się organizacja, oraz wskazanie, w jakim kierunku może iść jej procesowy rozwój. Podstawowym celem budowania modeli dojrzałości procesowej jest określenie etapów dochodzenia do dojrzałości. Zazwyczaj zawierają one charakterystykę każdego z poziomów oraz logiczny związek pomiędzy nimi.

Model z jęz. łac. oznacza miarę, wzór, sposób, według którego można coś wykonać. Modele są uproszczonym przedstawieniem złożonej rzeczywistości. Niemniej jednak stanowią znaczący dorobek współczesnych teorii naukowych. Prezentują strukturę, cechy, funkcjonowanie istniejącego lub projektowanego obiektu, dostarczając informacji umożliwiających jego poznanie [Leksykon zarządzania 2004, s. 343]. 
Szybko stały się popularnym instrumentem używanym do oceny i diagnozy w różnych dziedzinach oraz określania działań umożliwiających usprawnianie organizacji, a także do przeprowadzania analiz porównawczych między organizacjami [Duffy 2001]. Mają one charakter koncepcyjny, reprezentują ilościowo lub jakościowo etapy rosnącej zdolności elementów danego obiektu i umożliwiają ocenę stopnia osiągnięcia poszczególnych poziomów w odniesieniu do zdefiniowanych kryteriów [Kohlegger $i$ in. 2009]. W zarządzaniu procesowym są zapisem wiedzy o tym:

- jak powinny być realizowane sprawne i efektywne procesy,

- jakimi kryteriami posługiwać się w ocenie procesów,

- co należy robić, aby usprawnić procesy [Kania 2013, s. 79].

W literaturze przedmiotu wskazuje się na różne cele, jakim mogą służyć modele dojrzałości procesowej. Zalicza się do nich:

- cele opisowe (deskryptywne), modele są wykorzystywane jako narzędzia diagnostyczne, służące do ustalania stanu istniejącego (tzw. modele as-is),

- cele normatywne (preskryptywne), modele pozwalają określić przyszły poziom dojrzałości oraz dostarczają wskazówek, jak implementować poszczególne poziomy dojrzałości stosownie do spodziewanej poprawy zarządzania organizacjami. W związku z tym uznać można je za narzędzia doskonalenia, gdyż oprócz identyfikowania stanu obecnego opisują pożądany stan docelowy i dostarczają wskazówek dotyczących kolejnych kroków do wykonania oraz odnoszą się do mierników doskonalenia (tzw. modele to-be),

- cele porównawcze (komparatywne), modele dojrzałości procesowej pozwalają na wewnętrzne i zewnętrzne porównanie [Rosemann, de Bruin 2005]. Działania takie w swojej istocie podobne są do benchmarkingu.

Modele dojrzałości procesowej pozwalają zatem zdiagnozować, w którym miejscu na drodze do dojrzałości procesowej znajduje się organizacja, oraz pomagają wskazać niedostatki i sugerują, jak w pełni osiągnąć dany stopień dojrzałości. Wyznaczenie poziomu dojrzałości procesowej organizacji wymaga zbadania stopnia zastosowania elementów składających się na poszczególne determinanty, takich jak: identyfikacja i zdefiniowanie procesów, standaryzacja procesów, doskonalenie i stosowane techniki doskonalenia, pomiar rezultatów procesów, analiza efektywności i skuteczności procesów, funkcja właściciela procesów, struktura organizacyjna, kultura procesowa, system motywacyjny, świadomość wymagań i oczekiwań klienta, zarządzanie wiedzą o procesach [Skrzypek, Hofman 2010]. Stosowane modele posiadają zazwyczaj 5-6 poziomów. Przykładowo, w modelu Capability Maturity Model Integrated (CMMI) wyróżniono następujące poziomy dojrzałości:

- Poziom 1 - Procesy przypadkowe, niezorganizowane.

- Poziom 2 - Procesy powtarzalne, częściowo zorganizowane.

- Poziom 3 - Procesy zorganizowane i zidentyfikowane, lecz niemierzone

- Poziom 4 - Procesy zarządzane w oparciu o miary.

- Poziom 5 - Procesy nieustannie doskonalone [Bitkowska i in. 2011, s. 65]. 


\section{Różnorodność modeli dojrzałości procesowej}

Przy ocenie dojrzałości procesowej organizacji kluczowym krokiem jest wybór modelu, na którym oparta będzie ocena. Propozycje modeli pochodzą z różnych źródeł, należą do nich badania akademickie, zastosowania w przemyśle, międzynarodowych korporacjach czy w sektorze publicznym, np. model CAF. Modele różnią się też swoim zakresem. Część z nich odnosi się do udoskonalania procesów (de Bruin i Rosemann 2007), inne skupiają się na doskonaleniu zarządzania procesami (Rosemann i de Bruin 2005), a jeszcze inne na identyfikowaniu procesów, ich projektowaniu, wprowadzaniu i ocenie (Smith i Fingar 2004). W kilku modelach dojrzałość procesów scala się z dojrzałością procesów zarządczych (Smith i Fingar 2004). Można zauważyć, że dziedzinowe modele dojrzałości procesowej są rozwijane przede wszystkim przez praktyków oraz środowiska akademickie, natomiast modele ogólniejsze są własnością dużych organizacji lub są efektem programów rządowych [Kania 2013, s. 76].

Poszczególni autorzy modeli dojrzałości procesowej proponują zróżnicowane kryteria oceny poszczególnych stopni dojrzałości oraz różną ich liczbę, wśród nich znajdują się M. Hammer (2007), P. Harmon (2009), M. Roseman i J. vom Brocke (2010), M. Rohloff (2009), P. Willaert i in. (2007), K. Mc Cormack i in. (2009), A. M. Magdaleno i in. (2008), J. Zwicker i in. (2010). Niektóre modele dojrzałości procesowej są uważane za własność intelektualną firm konsultingowych i instytutów badawczych (Willaert i in. 2007, Melenovsky i Sinur 2006). Wskazać można takie, które zawierają jedynie ocenę warunków realizacji procesu albo odnoszą się do specyficznych typów procesów, przykładowo Process Condition Model (de Toro i Mc Cabe 1997) [Röglinger i in. 2012]. T. de Bruin i M. Rosemann dzielą modele dojrzałości na dwa rodzaje:

- modele, które oceniają pojedyncze, konkretne procesy lub ich zestawy,

- modele, które oceniają zdolność organizacji do zarządzania powiązanymi ze sobą procesami biznesowymi, nazywane często modelami BPM [de Bruin, Rosemann 2010].

Niniejsze opracowanie nawiązuje do tych drugich, których od początku lat 90. XX wieku opracowano bardzo wiele. Twierdzi się, że obecnie dostępnych jest około 150 różnych modeli dojrzałości procesowej [Spanyi 2004, za: Kalinowski 2011], a najbardziej rozpowszechnionymi są model Capability Maturity Model Integration (CMMI), będący rozwinięciem modelu CMM, oraz model BPMM opracowany przez Object Management Group. Na ich założeniach, uwzględniając również sposób pomiaru efektywności organizacji, który zaproponowali G.A. Rummler i A.P. Brache, bazują inne, szeroko opisywane w literaturze przedmiotu. Koncepcja ta wskazuje na potrzebę łączenia poziomów organizacji, procesów i stanowisk pracy z przyjętymi celami, sposobem zaprojektowania i sposobem zarządzania [Rummler, Brache 2000, s. 45]. Dostępne modele dojrzałości procesowej J. Auksztol i M. Chomuszko podzielili na cztery grupy: 
- grupa modeli opartych na Capability Maturity Model (CMM), w tym model CMMI,

- Business Process Maturity Model (BPMM), który jest własnością Object Management Group (OMG),

- modele branżowe, często inspirowane przez CMM/CMMI lub BPMM,

- bardziej ogólne modele, które zawierają pewne elementy dojrzałości procesowej, np. Information Technology Infrastructure Library (ITIL), który zawiera dedykowaną część związaną z dojrzałością procesową: Process Maturity Framework (PMF), czy modele oceny dojrzałości orientacji na jakość, w których skład wchodzi ocena wdrożenia podejścia procesowego, np. model EFQM [Auksztol, Chomuszko 2012, s. 32].

Według Ch. Benza i M. Reicharta współcześnie występuje sześć perspektyw badawczych procesów i na ich tle funkcjonują różne modele dojrzałości procesowej, opracowywane w celu dokonywania oceny realizacji procesów i ogólnego poziomu dojrzałości procesowej organizacji [Zimniewicz 2014, s. 86]. Autorzy ci mówią o:

- perspektywie odnoszącej się do organizacji procesów, ogranicza się ona do ustalenia następstw etapów w procesach, co umożliwia zdefiniowanie granic procesów, identyfikację ich treści oraz ewentualne łączenie,

- perspektywie polegającej na modelowaniu procesów, w której za pomocą narzędzi IT tworzona jest architektura procesów,

- perspektywie mającej rodowód japoński, w której chodzi o ciągłe, ewolucyjne doskonalenie procesów, odbywające się „małymi krokami”, nieburzące dotychczasowej architektury procesowej; zakłada partycypację pracowników we wprowadzaniu zmian w procesach,

- perspektywie mającej swe źródło w reengineeringu, w której dominuje pogląd, że doskonalenie procesów powinno przynieść natychmiastowy, na dużą skalę wzrost efektów,

- perspektywie nazywanej strategiczną, w której zakłada się, że istnieje mocne powiązanie doskonalenia procesów z zarządzaniem strategicznym. W centrum uwagi znajdują się tu procesy strategiczne i wspomagające, które tworzą wartość dodaną dla klientów,

- perspektywie dotyczącej przedsiębiorstw sieciowych, w których nie ma hierarchii, co jest traktowane jako dobra podstawa do doskonalenia procesów [Benz, Reichart 2003, s. 30].

\section{Korzyści stosowania modeli dojrzałości procesowej}

Zwolennicy stosowania modeli dojrzałości procesowej wskazują na wiele zalet związanych z ich stosowaniem. Wśród korzyści ekonomicznych wymienia się:

- obniżkę kosztów,

- skrócenie czasu realizacji procesów,

- poprawę jakości, 
- poprawę satysfakcji klientów,

- poprawę wskaźnika ROI [Goldenson, Gibson 2003].

W literaturze przedmiotu wymienia się też korzyści o charakterze organizacyjno-zarządczym, twierdząc, że ułatwiają one pracę menedżerom i usprawniają funkcjonowanie organizacji. W tym kontekście wskazuje się na:

- uporządkowanie zagadnień oraz integrację metod i technik w ramach jednego, spójnego podejścia,

- możliwość wykorzystania dobrych praktyk, wypracowanych często przez zespoły ekspertów, co ułatwia wdrażanie dopasowanych do danej organizacji rozwiązań,

- możliwość standaryzacji, mierzenia i monitorowania zagadnień, które dotychczas nierzadko były realizowane chaotycznie i doraźnie, bez spójnych ram i czyjejkolwiek kontroli,

- poprawę relacji z interesariuszami, a zwłaszcza z klientami, dostawcami i inwestorami, przez lepsze uwzględnianie ich potrzeb i oczekiwań,

- ułatwianie wdrażania stopniowych usprawnień w funkcjonowaniu przedsiębiorstwa przez wskazanie ścieżki doskonalenia danego obszaru,

- możliwość benchmarkingu i wymiany doświadczeń z innymi podmiotami stosującymi określony model dojrzałości [Głuszek, Kacała 2015, s. 29].

Modele oceny dojrzałości procesowej w zależności od potrzeb organizacji mogą być w praktyce wykorzystywane w różnych sytuacjach [Kalinowski 2011, s. 177]. Ich podstawowym celem jest identyfikacja obecnego poziomu dojrzałości procesowej oraz wskazanie możliwości jego podniesienia. $Z$ ich pomocą relatywnie prostsze może być doskonalenie procesów, głównie ze względu na odniesienie w nich do dobrych praktyk, które sugerują sprawdzone sposoby podwyższania dojrzałości procesowej oraz pozwalają unikać problemów z tym związanych [Rosemann, de Bruin 2005]. Powyższe wskazuje na to, że są nie tylko narzędziem diagnostycznym, ale również metodyką wspierającą doskonalenie procesów i zarządzanie nimi [Kania 2013, s. 80].

Określenie poziomu dojrzałości procesów jest ważne, a niektórzy wręcz twierdzą, że krytyczne dla stabilności prowadzenia działalności [Albliwi i in. 2014], określenia możliwości poprawy i zrównoważonego rozwoju, ponieważ orientacja na procesy nie pojawia się w organizacjach z dnia na dzień, jej rozwój, przejście z poziomów niespójnych, nieskoordynowanych działań do etapów uporządkowanych, zarządzanych i doskonalonych procesów wymaga wprowadzania wielu zmian, rozłożonych w czasie. Sama dojrzałość procesowa ma charakter stopniowalny, bazuje na ewolucyjnych i wielostopniowych zmianach, które prowadzą do osiągnięcia pożądanego poziomu dojrzałości procesowej.

W dochodzeniu do coraz większej dojrzałości pomocne są szczególnie te modele dojrzałości procesowej, które mają charakter przejścia i mówią, jakie kroki należy wykonać, aby od stanu istniejącego przejść do pożądanego (model to-do) [Kania 2013, s. 79]. Sugerują one wprowadzanie zmian w realizacji procesów i zawierają wskazania dotyczące sposobów funkcjonowania organizacji po wprowadzeniu zmian, 
rozumianych jako modyfikacja realizacji procesu, a często łańcucha powiązanych ze sobą procesów. Ułatwiają wprowadzanie zbioru działań zmieniających organizację, przedstawiając, jakie powinny być procesy i ich wzajemne oddziaływania na poszczególnych poziomach.

Według P. Cronemyra i M. Danielssona organizacje potrzebują modeli dojrzałości procesowej, ponieważ one pomagają zmniejszyć ryzyko niepowodzenia w zarządzaniu procesami i pomagają dopasować zmiany procesowe do dysponowanego czasu i budżetu, orientując przechodzenie na wyższe poziomy dojrzałości, na wzrost jakości produktów, przyjmując, że efektywniejsze procesy zapewniają wyższą jakość produktów [Cronemyr, Danielsson 2013]. Pomagają również sterować działaniami usprawniającymi procesy poprzez dostarczanie programu kolejnych zadań, wyznaczanie obszarów i określenie zbioru wskazówek do działania [Curtis, Alden 2007]. Często przyjmują formę zestawu wymagań i/lub wytycznych, które stanowią punkt wyjścia do wprowadzania zmian, pozwalających przejść na wyższe poziomy dojrzałości. Orientowanie zarządzania na procesy jest szczególnie trudne, ponieważ wprowadzane zmiany wymagają nadania nowego kierunku w myśleniu i działaniu wszystkich pracowników, a ich celem jest wzrost sprawności działania organizacji poprzez integrowanie działań wokół procesów i eliminację pojawiających się barier i oporów. Wraz ze wzrostem dojrzałości procesowej następuje przebudowa organizacji, wprowadzane zmiany mają charakter kompleksowy i długofalowy. W tej sytuacji stosowanie modeli dojrzałości procesowej systematyzuje wprowadzanie zmian, pozwala uniknąć niepewności, a z drugiej strony dostrzec, uświadomić i zrozumieć konieczne do zainicjowania działania. W modelach każdy poziom jest zazwyczaj dobrze zdefiniowanym zbiorem stanów, które powinny zostać osiągnięte w zrównoważony sposób, zbliżając organizację do osiągnięcia pełnej dojrzałości [Kania 2013, s. 80]. Kolejne poziomy, opierając się na poprzednich, odzwierciedlają coraz bardziej zaawansowaną orientację procesową. Modele umożliwiają również pomiar ilościowy i jakościowy uzyskiwanych rezultatów wprowadzanych zmian.

\section{Bariery stosowania modeli dojrzałości procesowej}

Modele dojrzałości procesowej mogą niewątpliwie stanowić wsparcie we wprowadzaniu zmian procesowych. Szczegółowo określają, które obszary zarządzania procesami muszą zostać poprawione i jakie cele muszą być osiągnięte, aby organizacja mogła usytuować się na określonym poziomie dojrzałości. Jednak trzeba mieć świadomość, że korzyści z ich stosowania nie są oczywiste, ich przydatność w zwiększaniu stopnia orientacji procesowej zależy od wielu czynników. Sam model uznać należy za jedno z narzędzi wspomagających coraz większe zorientowanie zarządzania na procesy, które wymaga niewątpliwie umiejętności stosowania. Pamiętać również należy, że w praktyce występuje zazwyczaj większa liczba różnych zależności, niż to jest przedstawiane w modelach, które w dużej mierze upraszczają rzeczywistość organizacyjną. Ważna jest tu ponadto determinacja najwyższego 
szczebla zarządzania, trzymanie kursu na podnoszenie dojrzałości procesowej, znajomość zagadnień procesowych i zaangażowanie pracowników. Stosowanie modeli dojrzałości procesowej automatycznie nie gwarantuje uzyskania, ani też utrzymania określonego poziomu dojrzałości. Jeśli realizacja już wdrożonych praktyk nie będzie podtrzymywana, łatwo będzie można utracić wysoką jakość procesów. Posługiwanie się modelami jest również obarczone pewnym ryzykiem niepowodzenia, które pojawia się wraz ze sztywnym trzymaniem się zapisów modelu bez elastycznego dopasowania do wymagań i praktyki konkretnej organizacji [Kania 2013, s. 83]. Jest to szczególnie istotne w obecnym, dynamicznym otoczeniu, które wręcz wymusza dynamiczne zarządzanie procesami i ich indywidualizację. Modelom zarzuca się też to, że mało miejsca poświęcają czynnikom, które wywołują konieczność wprowadzania zmian w procesach, skupiając się przede wszystkim na sugerowaniu przejścia do określonego „stanu końcowego” [Röglinger i in. 2012, s. 334], oraz że nie akcentują relacji: wyniki organizacji - efektywność procesów. W tej sytuacji możliwe jest przechodzenie na kolejne poziomy dojrzałości procesowej bez wskazania na jakiekolwiek efekty całych organizacji. Tymczasem wykazanie jednoznacznych związków między stosowaniem modeli dojrzałości procesowej a wynikami ekonomicznymi organizacji mogłoby być argumentem przekonującym, że ich stosowanie jest opłacalne. Tym bardziej że ma się wrażenie, że firmy doradcze przesadnie wręcz eksponują ich walory i potrzebę aplikacji, rysując zbyt optymistyczną perspektywę uzyskiwanych korzyści. Wyniki różnych badań [Dijkman, Lammers, Jong 2015; Raschke 2010] potwierdzają co prawda zależność między poziomem dojrzałości procesowej a efektywnością organizacji, jednakże ci sami autorzy podają w wątpliwość zasadność inwestowania w osiągnięcie najwyższego poziomu dojrzałości, który wiąże się z koniecznością ciągłego doskonalenia procesów i ponoszeniem w związku z tym określonych kosztów. R.M. Dijkman, S.V. Lammers, A. Jong podają przykłady przedsiębiorstw, którym do osiągania zadowalających wyników wystarcza stosunkowo niski, bo drugi poziom dojrzałości procesowej. Na tym poziomie pojawia się świadomość, że czynności realizowane przez poszczególne funkcje mają na siebie wpływ, że praca jednego wydziału stanowi punkt wyjścia do pracy drugiego. Istnieje zatem wiedza o procesach i związkach przyczynowo-skutkowych, zachowania i relacje między pracownikami zmieniają się z produktowych na prorynkowe [Nowosielski 2012, s. 358].

Niewątpliwie decyzja o stosowaniu modeli dojrzałości procesowej wiąże się z perspektywą ponoszenia wysokich nakładów na jego wdrożenie, wymaga inwestowania niejednokrotnie ograniczonych środków i stoi bez wątpienia w opozycji do aktualnych celów wielu organizacji, które ukierunkowują się na obniżanie kosztów. Jest to o tyle istotne, że jak przedstawia to raport Dojrzałość procesowa polskich organizacji (2016), właśnie wprowadzanie zarządzania procesami jest dla większości badanych organizacji sposobem na redukcję kosztów [www.Procesowcy.pl 2016]. W tej sytuacji silna presja na bieżącą efektywność, wyrażająca się w orientacji na wyniki, może być poważną przeszkodą w zainteresowaniu się modelami dojrzałości procesowej, 
stoi ona bowiem w konflikcie z ewolucyjnym dochodzeniem do lepszych rezultatów działania i stawia na szybką poprawę uzyskiwanych efektów [Lichtarski 2008, s. 15].

Wdrażaniu praktyk opisanych w modelach towarzyszy instytucjonalizacja form prowadzenia oceny, powoływane są zespoły odpowiedzialne za zbieranie i analizę danych potwierdzających przynależność do danego poziomu dojrzałości procesowej. Ocena zgodności z zapisami modelu przeprowadzana jest często przez ekspertów, którzy muszą być przeszkoleni w zakresie interpretacji modelu i metod oceny bieżącej sytuacji. Wśród metod dokonywanej oceny wymienia się: wywiady z wykonawcami i menedżerami procesów, przeglądy rezultatów procesów, przeglądy dokumentów i informacji związanych z realizacją procesu [Chrapko 2010, s. 255]. Ponadto przeprowadzana ocena może mieć charakter etapowy, przykładowo w modelu BPMM mowa jest o ocenie: początkowej, postępu, dostawców i potwierdzającej [BPMM 2008 , s. 5]. W przypadku modelów CMMI i BPMM ocenie towarzyszy sformalizowany zbiór wytycznych, a sama ocena może być przeprowadzana wyłącznie przez certyfikowanego rzeczoznawcę, co wiąże się z określonymi kosztami przeprowadzania takiej oceny [Dijkman i in. 2015, s. 3]. Do tego dochodzą jeszcze inne koszty związane z dopasowaniem organizacyjnym do nowego poziomu dojrzałości oraz koszty związane z aspektami społecznymi i tzw. miękkimi czynnikami zarządzania, jak np. dopasowaniem kultury organizacyjnej, stylów zarządzania i in.

Zdaniem R.M. Dijkmana, S.V. Lammersa, A. Jonga inwestowanie w podnoszenie dojrzałości procesowej powinno być poprzedzone wyznaczeniem granicznego progu, do którego jej zwiększanie jest dla organizacji opłacalne, a powyżej którego ponoszone w szerokim rozumieniu koszty przewyższają osiągane korzyści [Dijkman, Lammers, Jong 2015, s. 2]. Takie stanowisko koresponduje z opiniami, że modeli dojrzałości procesowej nie można traktować jako ,jednakowego przepisu” dla wszystkich organizacji. Ich stosowanie wymaga prowadzenia rachunku ekonomicznego i podejścia sytuacyjnego, uwzględniającego uwarunkowania zarówno wewnętrzne, jak i zewnętrzne funkcjonowania organizacji. Modele te powinny umożliwić znalezienie własnej „drogi do doskonałości organizacyjnej” [Gomez Gomez i in. 2015, s. 497].

Poszczególne bariery upowszechniania modeli dojrzałości procesowej podzielić można na wewnętrzne i zewnętrzne. Jedne i drugie mogą mieć różny charakter. Poniżej w tabeli 1 sklasyfikowano bariery o charakterze wewnętrznym, związane $\mathrm{z}$ wewnętrznymi uwarunkowaniami funkcjonowania organizacji, uznając, że to one w dużej mierze mają największe znaczenie. Przeszkody zewnętrzne natomiast mają związek z cechami otoczenia, trendami i pewnymi modami na stosowanie określonych narzędzi wspomagających zarządzanie branżą, w której funkcjonuje podmiot, oraz wymaganiami partnerów biznesowych, kooperantów, dostawców i odbiorców. Rozpowszechnianiu modeli sprzyjać mogą regulacje nakazujące wręcz dostarczanie dowodów na dojrzałość, tak jak ma to miejsce np. w Stanach Zjednoczonych w odniesieniu do sektora obronności, gdzie poziom dojrzałości procesowej utożsamiany jest z mniejszym ryzykiem podejmowanych działań. 
Tabela 1. Główne wewnętrzne bariery upowszechniania modeli dojrzałości procesowej

\begin{tabular}{|c|c|}
\hline Charakter bariery & Wyszczególnienie \\
\hline Zarządcze & 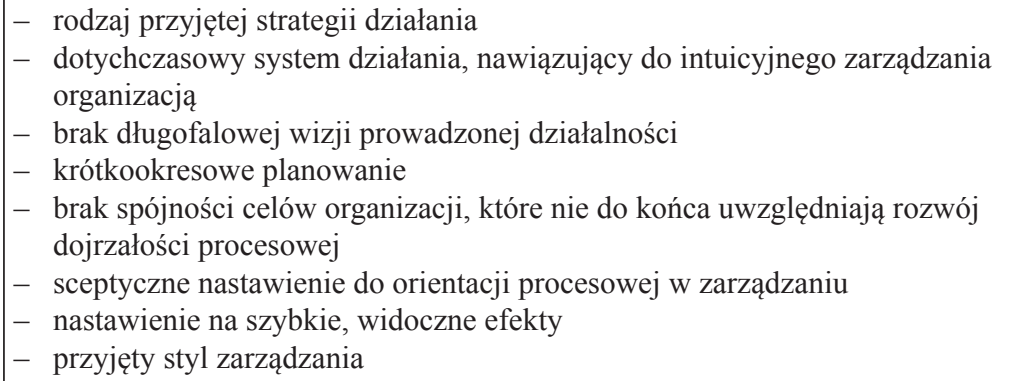 \\
\hline Finansowe & $\begin{array}{l}\text { - } \text { koszty przygotowania się do stosowania modelu } \\
\text { - koszty dokonywanych analiz i porównań } \\
\text { - } \text { koszty oceny dokonywanej przez zewnętrznych ekspertów } \\
\text { - } \text { koszty dopasowania rzeczywistości organizacyjnej do danego poziomu } \\
\text { dojrzałości }\end{array}$ \\
\hline Personalne & 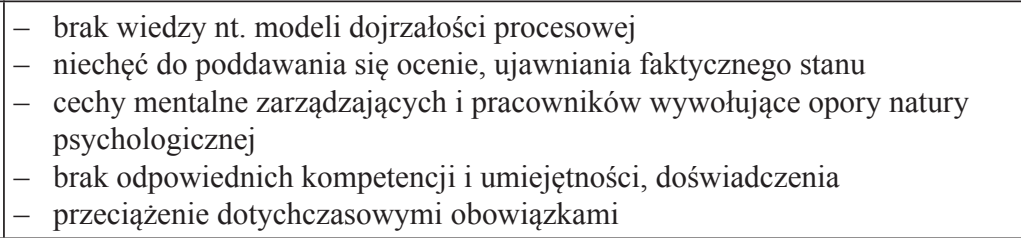 \\
\hline Kulturowe & $\begin{aligned} \text { - } & \text { obowiązująca, zachowawcza kultura organizacyjna } \\
\text { - } & \text { niepostrzeganie zmiany organizacyjnej jako wartości } \\
\text { - } & \text { brak zaangażowania kadry zarządzającej, dominacja biernego stylu } \\
& \text { zarządzania }\end{aligned}$ \\
\hline Organizacyjne & 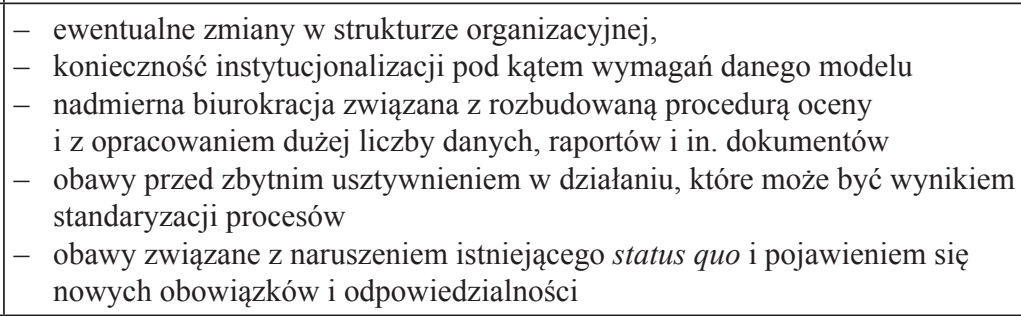 \\
\hline Techniczne & $\begin{array}{l}\text { - duża liczba opracowanych modeli dojrzałości procesowej utrudniająca } \\
\text { dokonanie wyboru } \\
\text { - obszerne, trudne w interpretacji opisy wymagań poszczególnych modeli } \\
\text { - duża liczba przedmiotów oceny, znajdujących się na wejściu, wyjściu } \\
\text { i w trakcie realizacji procesów }\end{array}$ \\
\hline
\end{tabular}

Źródło: opracowanie własne.

\section{Zakończenie}

Dojrzałe organizacje o orientacji procesowej są wynikiem świadomych działań zarządzających. Ich kształtowaniu towarzyszą zmiany o charakterze organizacyjnym, 
technicznym, psychologicznym i społecznym. Są to zazwyczaj zmiany mocno złożone. Dlatego też zarządzający poszukują narzędzi, które ułatwią ich wprowadzanie i będą gwarantować osiągnięcie zaplanowanych efektów. Ich przykładem są niewątpliwie modele dojrzałości procesowej, których liczebność oraz duża dynamika opracowywania kolejnych powoduje chaos na poziomie poznawczym oraz na poziomie aplikacyjnym. Pojawiają się problemy i obawy związane z ich doborem, wyborem, wdrożeniem. Problemem może też być włączenie wybranego modelu do dotychczasowego systemu zarządzania. Dynamiczny ich rozwój wywołuje konieczność zadania pytania o ich użyteczność. Jest to kwestia trudna, ponieważ w dużej mierze, jak wskazano w opracowaniu, trudno jest jednoznacznie powiązać uzyskiwane wyniki ekonomiczne ze zwiększaniem dojrzałości procesowej. Związek ten nie jest do końca jednoznaczny i nie da się z pewnością stwierdzić, że każda firma, która podejmie wysiłek wprowadzania modelu do swojej praktyki zarządzania, w krótkim czasie odczuje poprawę efektów swoich procesów i poprawę wyników finansowych [Haffer 2011, s. 462].

Praktyczna przydatność omawianych modeli jest niewątpliwie widoczna na etapie dokonywania diagnozy stanu dojrzałości procesowej, jednak dalsze ich stosowanie uzależnione powinno być od ustalenia potrzeb jej zwiększania. W tej sytuacji należałoby wziąć pod uwagę stopień ukierunkowania strategii organizacji na rozwój procesowego zarządzania, spodziewany wpływ zastosowania modeli dojrzałości procesowej na poprawę jasno zdefiniowanych wyników, możliwości dopasowania stosowania modelu do dotychczasowego systemu zarządzania, spodziewany stopień trudności i koszty wprowadzania. Trzeba mieć bowiem na uwadze, że zwiększaniu dojrzałości procesowej służyć mogą także różne metody i koncepcje zarządzania, jak np. TQM, Balanced Scorecard, zarządzanie wiedzą, które nie wymagają wprost stosowania modelu dojrzałości procesowej, chociaż, tak jak to ma miejsce przy TQM, mogą go zalecać. Literatura przedmiotu dostarcza też wyników badań, które sugerują pozytywny związek pomiędzy wysoką innowacyjnością organizacji i dojrzałością procesową [Dijkman i in. 2015, s. 13]. Stwierdza się, że wprowadzanie przyrostowych innowacji sprzyja zwiększaniu poziomu dojrzałości procesowej.

W tej sytuacji można mówić o istotnych ograniczeniach upowszechniania modeli dojrzałości procesowej. Mają one swoje źródło przede wszystkim w wewnętrznych właściwościach organizacji, chociaż mogą też pozostawać pod wpływem oddziaływania uwarunkowań zewnętrznych. Wykazanie jednoznacznych związków między stosowaniem modeli dojrzałości procesowej a wynikami ekonomicznymi całej organizacji mogłoby być argumentem przekonującym kadrę menedżerską do ich implementacji. Autorka ma świadomość, że przeprowadzone w opracowaniu rozważania należałoby skonfrontować z doświadczeniami organizacji, wzbogaciłoby to przeprowadzone badania literaturowe. Tym samym zagadnienia te mogłyby stanowić punkt wyjścia do realizacji badań empirycznych. 


\section{Literatura}

Albliwi S.A., Antony J., Arshed N., 2014, Critical Literature Review on Maturity Models for Business Process Excellence, IEEE International Conference on Industrial Engineering and Engineering Management, Malaysia, http://www.academia.edu/9930946/Critical_Literature_Review_on_Maturity_Models_for_Business_Process_Excellence (20.06.2015).

Auksztol J., Chomuszko M., 2012, Modelowanie organizacji procesowej, Wydawnictwo Naukowe PWN, Warszawa.

Benz Ch., Reichart M., 2003, Abläufe haben viele Gesichter, New Management, no. 11.

Bitkowska A., 2009, Zarzadzanie procesami biznesowymi w przedsiębiorstwie, Vizja Press \& IT, Warszawa.

Bitkowska A., Kolterman K., Wójcik G., Wójcik K., 2011, Zarządzanie procesami w przedsiębiorstwie. Aspekty teoretyczno-praktyczne, Difin, Warszawa.

BPMM Specyfication. Version 1.0, Object Management Group, June 2008, http;//www.omg.org/spe/ BPMM/1.0/PDF.

Brajer-Marczak R., 2012, Efektywność organizacji z perspektywy modelu dojrzatości procesowej, Journal of Management and Finance, vol. 10, no. 1, part 3, Wydawnictwo Wydziału Zarządzania Uniwersytetu Gdańskiego, Gdańsk.

vom Brocke J., Rosemann M., 2015, Handbook on Business Process Management 1 Introduction, Methods and Information Systems, Springer-Verlag, Berlin-Heidelberg.

Chrapko M., 2010, CMMI - Doskonalenie procesów w organizacji, PWN, Warszawa.

CMMI-DEV 2010, Software Engineering Institute, Carnegie Mellon University.

Cronemyr P., Danielsson M., 2013, Process Management 1-2-3 - a maturity model and diagnostics tool, Total Quality Management \& Business Excellence, vol. 24, no. 7-8.

Curtis B., Alden J., 2007, The Business Process Maturity Model (BPMM), what, why and how?, Business Process Trends, February.

De Bruin T., Rosemann M., 2010, Using the Delphi technique to identify BPM capability areas, Australasian Conference on Information Systems, www.bptrends.com.

Dijkman R.M., Lammers S.V., Jong A., 2015, Properties that influence business process management maturity and its effect on organizational performance, Information Systems Frontiers, Springer, http://repository.tue.nl/f9167029-94c4-4e6d-ba38-49a0f84fd434.

Duffy J., 2001, Maturity models: Blueprints for e-Volution, Strategy \& Leadership, vol. 29, iss. 6.

Głuszak E., Kacała J., 2015, Metodologiczne podstawy projektowania modeli dojrzałości, Nauki o Zarządzaniu, Management Sciences, Wydawnictwo Uniwersytetu Ekonomicznego we Wrocławiu, Wrocław.

Goldenson D.R., Gibson D.L., 2003, Demonstrating the Impact and Benefits of CMMI ${ }^{\circledR}$ : An Update and Preliminary Results, Special Report CMU/SEI-2003-SR-009, Carnegie Mellon Software Engineering Institute, Pittsburgh, October, http://www.sei.cmu.edu/reports/03sr009.pdf.

Gomez Gomez J., Martinez Costa M., Martínez Lorente A.R., 2015, An in-depth review of the internal relationships of the EFQM model, The TQM Journal, vol. 27, iss. 5.

Haffer R., 2011, Samoocena i pomiar wyników działalności w systemach zarządzania przedsiębiorstw, Wydawnictwo Naukowe Uniwersytetu Mikołaja Kopernika, Toruń.

Kalinowski T.B., 2011, Model oceny dojrzałości procesów, Acta Universitatis Lodziensis, Folia Oeconomica nr 258.

Kania K., 2013, Doskonalenie zarządzania procesami biznesowymi w organizacji z wykorzystaniem modeli dojrzałości i technologii informacyjno-komunikacyjnych, Wydawnictwo Uniwersytetu Ekonomicznego w Katowicach, Katowice.

Kohlegger M., Maier R., Thalmann S., 2009, Understanding Maturity Models, Results of a Structured Content Analysis, Proceedings of I-KNOW' 09 and I-SEMANTICS '09, Graz, Austria. 
Kucińska-Landwójtowicz A., Kołosowski M., 2012, Determinanty dojrzałości procesowej organizacji, http://www.ptzp.org.pl/files/konferencje/kzz/artyk_pdf_2012/p059.pdf.

Leksykon zarządzania, 2004, Difin, Warszawa.

Lichtarski J., 2008, Nowe tendencje w zarządzaniu organizacjami, Przedsiębiorczość i Zarządzanie, tom IX, zeszyt 2, Wydawnictwo SWSPiZ w Łodzi, Łódź.

Nolan R.L., Gibson C.F., 1974, Managing the Four Stages of EDP Growth, Harvard Business Review, January-February, vol. 52.

Nowosielski S., 2012, Dojrzałość procesowa a wyniki ekonomiczne organizacji, Prace Naukowe Uniwersytetu Ekonomicznego we Wrocławiu, nr 264, Orientacja na wyniki-modele, metody i dobre praktyki, red. T. Borys, P. Rogala, UE, Wrocław.

Pöppelbub ß., Röglinger M., 2011, What makes a useful maturity model? A framework of general design principles for maturity models and its demonstration in BPM, ECIS 2011 Proceedings. Paper 28, http://aisel.aisnet.org/ecis2011/28.

Pullen W., 2007, A public sector HPT maturity model, Perform Improvement, vol. 46, no. 4.

Raschke R.L., Ingraham L.R, 2010, Business Process Maturity's Effect on Performance, AMCIS 2010 Proceedings, http://aisel.aisnet.org/cgi/viewcontent.cgi?article=1408\&context=amcis2010.

Rohloff M., 2009, Case study and maturity model for business process management implementation, International conference on BPM (s. 128-142), Springer, Berlin-Heidelberg.

Röglinger M., Pöppelbuß J., Becker J., 2012, Maturity models in business process management, Business Process Management Journal, vol. 18, no. 2.

Rosemann M., de Bruin T., 2005, Application of a holistic model for determining BPM Maturity, BPTrends, February, http://bpm-training.com/wpcontent/uploads/2010/04/applicationholistic.pdf.

Rummler G.A., Brache A.P., 2000, Podnoszenie efektywności organizacji. Jak zarzadzać białymi plamami w strukturze organizacyjnej, PWE, Warszawa.

Skrzypek E., 2012, Wyznaczniki dojrzałości jakościowej w świetle wyników badań, Prace Naukowe Uniwersytetu Ekonomicznego we Wrocławiu, UE, Wrocław.

Skrzypek E., Hofman M., 2010, Zarzadzanie procesami w przedsiębiorstwie: identyfikowanie, pomiar, usprawnianie, Oficyna a Wolters Kluwer business, Warszawa.

Zimniewicz K., 2014, Teoria i praktyka zarządzania. Analiza krytyczna, PWE, Warszawa.

www.Procesowcy.pl, Raport: dojrzałość polskich przedsiębiorstw 2016.

www.sjp.pl 